\title{
Purification of endoglucanase produced by Penicillium citrinum isolated from Amazon
}

\author{
Anita Lima de Souza ${ }^{1 *}$, Pamella Suely Santa Rosa Pimentel ${ }^{2}$, Edmar Vaz de Andrade², Spartaco Astolfi-Filho ${ }^{1,2}$, \\ Carlos Gustavo Nunes-Silva²
}

From 5th Congress of the Brazilian Biotechnology Society (SBBIOTEC)

Florianópolis, Brazil. 10-14 November 2013

\section{Background}

The cellulolytic enzyme complex has many important biotechnological applications such as beverage, textile, food, paper and cellulose industries, as well as in degradation of lignocellulosic for ethanol biofuel production [1]. According to the enzymatic activity, cellulolytic complex is subdivided in three classes: endoglucanases, exoglucanases and $\beta$-D-glycosidases.

Endoglucanases (endo- $\beta$-1,4-glucanase, EC 3.2.1.4) are responsible to initiate cleavage, hydrolyzing randomly internal regions from the amorphous cellulose fiber structures, releasing oligosaccharides from different grades of polymerization. These will be hydrolyzed by exoglucanases releasing cellobiose followed by $\beta$-D-glycosidades being hydrolyzed to glucose [1].

Penicillium citrinum has worldwide occurrence. Commonly in the soil, this specie is described as good xylanase and cellulase producer [2,3]. This work describes liquid chromatography to separate endoglucanases of Penicillium citrinum supernatant from submerse fermentation process.

\section{Methods}

Suspension of $1 \mathrm{~mL}$ P. citrinum spores $\left(6.4 \times 10^{6}\right)$ was inoculated in $200 \mathrm{~mL}$ submerse fermentation medium [4] containing $\mathrm{CMC}$ as carbon source for 10 days $/ 28^{\circ} \mathrm{C} /$ $150 \mathrm{rpm}$. Every 24 hours was sampled $6 \mathrm{~mL}$ aliquots, centrifuged and right after the supernatant storage at $4^{\circ}$ C. A pool was made of collected points from 72 to 240 hours. It was concentrated in SpeedVac (Thermo) for final volume of $1.5 \mathrm{~mL}$, filtrate $(0.45 \mu \mathrm{m})$ and injected in chromatograph column Superdex 75 10/300 GL (GE Healthcare) previously equilibrated with sodium citrate

Biotech Amazonia LTDA-ME - BIOTECH AM, Manaus, Brazil Full list of author information is available at the end of the article buffer at $50 \mathrm{mM} \mathrm{pH} 4.8$. Fractions of $1.5 \mathrm{~mL}$ was collected in a flux of $0.6 \mathrm{~mL} / \mathrm{min}$ in 1.5 column volumes (CV) using Akta Purifier (GE Healthcare). Fractions were analyzed by CMCase activity [5], protein dosage with BCA kit (Thermo Scientific) and SDS-PAGE 12\%.

\section{Results and conclusions}

It was observed a elution profile with three peaks from purification of $12 \mathrm{~mL}$ (pool) from culture supernatant, corresponding to the fractions $7,8,11$ and 16 , containing $60,60,250$ and $30 \mu \mathrm{g} / \mathrm{mL}$ of proteins, respectively. By analysis in SDS-PAGE a band with $33 \mathrm{kDa}$ in fractions 7 and 8 was detected, matching for endoglucanases of genera Penicillium, which can vary from 26 to 50 $\mathrm{kDa}$. Only fraction 7 and 8 had CMCase activity $(0.4$ and $0.3 \mathrm{U} / \mathrm{mL}$, respectively), in which 1 unit is the necessary quantity to release $1 \mu \mathrm{mol} / \mathrm{min}$ of hydrolyzed product. The specific activity CMCase was 6.6 and 4.4 $\mathrm{U} / \mathrm{mg}$ for 7 and 8 fractions, respectively. Chromatographic profile obtained for each induction time (72 to 240 hours) was comparable to the obtained for the pool, being the analysis referring to the protein content and enzymatic activity in progress.

\section{Acknowledgements}

Biotech Amazonia LTDA-ME, FAPEAM, CNPq and CAPES.

\section{Authors' details}

${ }^{1}$ Biotech Amazonia LTDA-ME - BIOTECH AM, Manaus, Brazil. ${ }^{2}$ Universidade Federal do Amazonas, UFAM, Manaus, AM, Brazil.

\section{Published: 1 October 2014}

\section{References}

1. Castro AM, Pereira N Jr: Produção, Propriedades e Aplicação de Celulases na Hidrólise de Resíduos Agroindustriais. Química Nova 2010, 33(1):181-188.

2. Wakiyama M, Tanaka $H$, Yoshihara $K$, Hayashi S, Ohta K: Purification and Properties of Family-10 Endo-1,4- $\beta$-Xylanase from Penicillium citrinum 
and Structural Organization of Encoding Gene. Journal of Bioscience and Bioengineering 2008, 105(4):367-374.

3. Ruegger MJS, Tauk-Tornisielo SM: Atividade da celulase de fungos isolados do solo da Estação Ecológica de Juréia-Itatins, São Paulo, Brasil. Revista Brasileira de Botanica 2004, 27(2):205-211.

4. Szijártó N, Szengyel Z, Lidén G, Réczey K: Dynamics of Cellulase

Production by Glucose Grown Cultures of Trichodermareesei Rut-C30 as a Response to Addition of Cellulose. Applied Biochemistry and Biotechnology 2004, 113:115-124.

5. Ghose TK: Measurement of Cellulase Activities. Pure and Applied Chemistry 1987, 59(2):257-268.

doi:10.1186/1753-6561-8-S4-P221

Cite this article as: de Souza et al.: Purification of endoglucanase

produced by Penicillium citrinum isolated from Amazon. BMC Proceedings 2014 8(Suppl 4):P221.

\section{Submit your next manuscript to BioMed Central} and take full advantage of:

- Convenient online submission

- Thorough peer review

- No space constraints or color figure charges

- Immediate publication on acceptance

- Inclusion in PubMed, CAS, Scopus and Google Scholar

- Research which is freely available for redistribution

Submit your manuscript at www.biomedcentral.com/submit 